\title{
Neonatal Perforation of Meckel Diverticulum: About Two Cases
}

\section{Fairouz Ayari', Radhouane Achour ${ }^{2}$, Abir Boussetta', Myriam Cheour', Takoua Bensmail'1, Samia Kacem ${ }^{1}$, Khaled Neji $^{2}$}

${ }^{1}$ Neonatology intensive care unit of the Maternity and Neonatology Center of Tunis, Tunisia

${ }^{2}$ Emergency department of the Maternity and Neonatology Center of Tunis, Tunisia

\begin{abstract}
Two cases of neonatal perforation of Meckel's diverticulum (MD) are reported. The clinical course showed the appearance of pneumoperitoneum successively at $20 \mathrm{~h}$ and the 7th day of life. Laparotomy revealed Meckel's perforation, which was associated with meconium peritonitis in the second case.
\end{abstract}

Although rare, MD should be kept in mind as one cause of gastrointestinal perforation in neonate.

Keywords: Newborn; Meckel's diverticulum; Intestinal perforation; Pneumoperitoneum; Premature

\section{Introduction}

Gastrointestinal perforation is a common situation in neonatology which complicated most often the evolution of necrotizing enterocolitis in premature with a low weight of birth. In other cases, gastrointestinal perforation can be iatrogenic or occurring spontaneously without signs of enterocolitis. We report two cases of intestinal perforation of MD in the first days of life.

\section{Case 1}

A male baby, 28 week gestation weighing $1400 \mathrm{~g}$ was born by urgent cesarean section for chorioamniotitis. He was born to a 31 year old primipara mother with no medical history. The Apgar score was 8 at 1 min and 9 at $5 \mathrm{~min}$, the infant was transferred to our neonatal intensive care unit with a mild respiratory distress. Routine thoraco abdominal radiograph taken $10 \mathrm{~h}$ after birth showed none expanded stomach and a dilated intestinal loop beneath the liver edge. Therefore, he was treated in nil-by-mouth status and was supplied with intravenous fluid [1-5]. Clinically the abdomen was progressively distended but palpated softly without tenderness. An abdominal X-ray was performed again at 20 $\mathrm{h}$ of age and showed pneumoperitoneum. All vital signs were stable except mild tachypnea. An emergency operation was performed $24 \mathrm{~h}$ after birth under a suspected diagnosis of gastrointestinal perforation. Before the operation, no meconium was passed. At laparotomy, a wide- based Meckel's diverticulum was found located $12 \mathrm{~cm}$ above the ileocecal valve with several thin-walled irregular bulges in the antimesenteric side. A tiny perforation was found over one bulge. The perforation was a blowout-like lesion and the appearance of the surrounding bowel was healthy without any inflammatory reaction. A wedge resection of the intestine with end-to-end anastomosis was performed. The postoperative course was uneventful [6-10].

\section{Case 2}

A $750 \mathrm{~g}$ boy was born by a normal vaginal delivery at 26 weeks' gestation. He was born of a 38 year old multigravida nulliparous mother who was followed for an incompetent cervix [11]. The Apgar score was 8 at $1 \mathrm{~min}, 9$ at $5 \mathrm{~min}$. Severe respiratory distress was noted immediately after birth necessitating his rapid transfer to our intensive care unit. On admission, he had cyanosis and severe respiratory distress [12-14]. The diagnosis of hyaline membrane disease was confirmed by the chest radiograph. Clinical outcome was favorable after surfactant administration. The infant presented at the $7^{\text {th }}$ day of life severe apnea requiring mechanical ventilation with oxygen requirement of $21 \%$ [15]. The chest radiograph was normal but the abdomen radiograph showed a pneumoperitoneum. The infant had a soft and no distending abdomen. An emergency laparotomy was performed on suspicion of a gut perforation. At laparotomy, a perforated MD was found $10 \mathrm{~cm}$ before the ileocecal valve, with meconium peritonitis. The appearance of the surrounding bowel was healthy. A segmental resection of the intestine with a stoma was performed. No aerobic or anaerobic organisms were cultured in the effusion taken from the peritoneal cavity [16-19]. Our patient recovered well from surgery. He required a prolonged total parenteral nutrition via a central venous catheter.

\section{Discussion}

MD is a vestigial remnant of the omphalomesnteric duct which is caused by an incomplete obliteration of the vitelline duct. Tt is the most common malformation of the gastrointestinal tract and is present in approximately $2 \%$ of the population [1]. Most of these are asymptomatic and occur during childhood in the first two years of life, with a male-to-female ratio of 2:1 [2]. The most common symptoms are gastrointestinal bleeding, bowel obstruction and diverticulitis [20].

Symptomatic MD in neonates is rare. The most common presenting symptoms is bowel obstruction [3], gastrointestinal bleeding was reported in one case [4]. Perforation of MD in neonates is rare, a review of the literature revealed only 22 cases from 1953 to 2016 with a sex ratio equal to $4.6(\mathrm{M} / \mathrm{F}: 14 / 3)$ and a gestational age ranging from 28 to 41 weeks (Table 1 ). The onset of symptoms was between 1 day of life and 17 [21,22]. Our patients were very preterm babies born at 28 and 26 week gestation, the pneumoperitoneum was discovered during abdomen distension in the first case, incidentally on the thoraco-abdominal $\mathrm{x}$-ray in the other patient. There are risk factors predisposing to MD perforation such us antenatal and postnatal steroid therapy, hypoxia, and poor intrauterine blood flow, congenital absence of the muscles in the gastrointestinal wall and exchange transfusion for hemolytic disease $[5,23]$. Our two babies actually received antenatal steroid therapy [24].

${ }^{*}$ Corresponding author: Feirouz Ayari, Neonatology intensive care unit of the Maternity and Neonatology Center, TUNIS, 1110, Tunisia, Tel: 0021692035624; E-mail: ayarifeirouz@yahoo.fr

Received December 07, 2016; Accepted January 08, 2017; Published January 16, 2017

Citation: Ayari F, Achour R, Boussetta A, Cheour M, Bensmail T, et al. (2017) Neonatal Perforation of Meckel Diverticulum: About Two Cases. Health Care Current Reviews 5: 183. doi: 10.4172/2375-4273.1000183

Copyright: @ 2017 Ayari F, et al. This is an open-access article distributed under the terms of the Creative Commons Attribution License, which permits unrestricted use, distribution, and reproduction in any medium, provided the original author and source are credited. 
Citation: Ayari F, Achour R, Boussetta A, Cheour M, Bensmail T, et al. (2017) Neonatal Perforation of Meckel Diverticulum: About Two Cases. Health Care Current Reviews 5: 183. doi: 10.4172/2375-4273.1000183

Page 2 of 2

\begin{tabular}{|c|c|c|c|c|c|c|c|}
\hline Authors & Sex & Week gestation & Weight (g) & $\begin{array}{l}\text { Age at pres- } \\
\text { entation (d) }\end{array}$ & Clinical picture & Heterotopic tissue & Histology \\
\hline Abramson [6] & Female & $?$ & 3742 & 5 & Peritonitis & None & Inflammation \\
\hline Coppes et al. [7] & Male & 32 & 1780 & 3 & Pneumoperitoneum & None & $\begin{array}{c}\text { Inflammation and } \\
\text { necrosis }\end{array}$ \\
\hline Rogers [8] & Male & $?$ & 2300 & Birth & Perforated viscus & None & Inflammation \\
\hline Lin et al. [9] & Male & 36 & 2450 & 4 & Perforated viscus & None & Inflammation \\
\hline Mc Manus et al. [10] & Male & $?$ & 2268 & $8 \mathrm{H}$ & Peritonitis & None & Inflammation \\
\hline Yeh et al. [11] & Male & $?$ & $?$ & 5 & Intestinal & None & Inflammation \\
\hline Canty et al. [12] & Male & $?$ & 4500 & 8 & Necrotizing enterocolitis & Pancreatic mucosa & Ectopic mucosa \\
\hline Zahraa et al. [13] & Male & Full term & 2070 & 3 & Necrotizing peritonitis & None & Inflammation \\
\hline Wright and Bhagwandeen [14] & Male & Full term & 3515 & Birth & Strangulated inguinal hernia & Gastric mucosa & Inflammation \\
\hline Rosza and Gross [15] & Female & $?$ & $?$ & Died at $9 \mathrm{H}$ & Meconium peritonitis & None & Inflammation \\
\hline Chang et al. [3] & Male & 33 & 2040 & $13 \mathrm{H}$ & Pneumoperitoneum & None & Inflammation \\
\hline Ford and Wooley [16] & $?$ & 37 & 1900 & 1 & Pneumoperitoneum & Pancreatic mucosa & $\begin{array}{c}\text { Inflammation and } \\
\text { necrosis }\end{array}$ \\
\hline Gandy et al. [17] & Male & Full term & 4500 & 8 & Bowel obstruction & Pancreatic mucosa & Inflammation \\
\hline Kumar et al. [18] & Male & $?$ & 2300 & 5 & Bowel obstruction & None & Inflammation \\
\hline Sy et al. [19] & Female & 40 & 3200 & 3 & Pneumoperitoneum & None & Inflammation \\
\hline Chang et al. [3] & Male & 33 & 2040 & 1 & Pneumoperitoneum & None & Focal muscular defect \\
\hline Oyachi et al. [20] & Male & Full term & 3060 & 17 & Bowel obstruction & None & Inflammation \\
\hline Aguayo et al. [21] & $?$ & 28 & 810 & 6 & Pneumoperitoneum & None & Inflammation \\
\hline Alkan et al. [22] & Female & 38 & 2800 & 1 & Pneumoperitoneum & None & Inflammation \\
\hline Bertozzi et al. [1] & Male & 34 & 2500 & 5 & Pneumoperitoneum & None & No inflammation \\
\hline Borgi et al. [23] & Male & 29 & 1400 & $3 \mathrm{H}$ & Gut perforation & None & Inflammation \\
\hline Smolkin et al. [24] & Male & 28 & 1200 & 4 & Pneumoperitoneum & None & No inflammation \\
\hline
\end{tabular}

Table 1: Reported cases of neonatal Meckel's diverticulum in the literature.

\section{Conclusion}

Because perforation of $\mathrm{MD}$ is the newborn is very rare, early recognition and prompt management with surgical intervention is essential for a positive outcome.

\section{References}

1. Bertozzi M, Melissa B, Radicioni M, Magrini E, Apignani A (2013) Symptomatic Meckel's diverticulum in new-born. Pediatr Emer Care 29: 1002-1005.

2. Benson CD (1978) Surgical implications of Meckel's diverticulum. Pediatric Surgery. Year Book Medical Publishers, Chicago, IL: 955Y960.

3. Chang YT, Lin JY, Huang YS (2006) Spontaneous perforation of Meckel's diverticulum without peritonitis in a new born: Report of a case. Surg Today 36: 1114-1117.

4. Sinha CK, Fishman J, Clarke SA (2009) Neonatal Meckel's diverticulum Spectrum of presentation. Pediatr Emerg Care 25: 348-349.

5. Lai MW, Hwang FM, Yeh YC, Chen SY, Kong MS, et al. (2014) Diverse presentation in pediatric Meckel's diverticulum: A review of 100 cases. Huang Pediatr Neonatol 55: 369-375.

6. Ambramson DJ (1991) Perforation of Meckel's diverticulum, peritonitis and intestinal obstruction in new-born with survival. Am J Dis Child 100: 147-151.

7. Coppes MJ, Roukema JA, Bax NM (1991) Scrotal pneumatocele: A rare phenomenon. J Pediatr Surg 26: 1428-1429.

8. Rogers CS (1964) Pneumoperitoneum in the new-born. Surgery 56:842-845.

9. Lin HP, Ong TH, Prathap K (1978) Perforation of Meckel's diverticulum in the new-born. J Singapore Pediatr Soc 20: 54-55.

10. McManus JE, Rao HK, Cochran RA Jr, Elhassani SB (1980) Perforation of Meckel's diverticulum in the new-born. J S C Med Assoc 76: 273-275.

11. Yeh JT, Lai HS, Duh YC (1996) Perforated Meckel's diverticulum in a neonate. J Formos Med Assoc 95: 644-645.

12. Canty T, McGuid MM, Eraklis AJ (1975) Perforation of Meckel's diverticulum in infancy. J Pediatr Surg 10: 189-193.
13. Zahraa J, Abu-Ekteish F, Al Bassam AR, Nosir AA (2003) Perforated Meckel's diverticulum in a neonate mimicking necrotizing enterocolitis. Pediatr Emerg Care 19: 418-419.

14. Wright JE, Bhagwandeen SB (1986) Antenatal perforation of Meckel's diverticulum presenting as an inflamed hydrocele. J Pediatr Surg 21: 989-990.

15. Rosza S, Gross RJ (1953) Intrauterine perforation of Meckel's diverticulum. Am J Roentgenol Radium Ther Nucl Med 69: 944-947.

16. Ford EG, Wooley MM (1992) Tracheoesophageal fistula associated with perforated Meckel's diverticulum. J Pediatr Surg 27: 1223-1224.

17. Gandy J, Byrne P, lees G (1997) Neonatal Meckel's diverticulum inflammation with perforation. J Pediatr Surg 32: 750-752.

18. Kumar P, Ojha P, Singh UK (1998) Spontaneous perforation of Meckel's diverticulum in a neonate. Indian Pediatr 35: 906-908.

19. Sy ED, Shan YS, Yang YR (2006) Hirschsprung's disease, a rare precipitating factor in neonatal perforated Meckel's diverticulum. J Pediatr Surg 41: 13191321.

20. Oyachi N, Takano K, Hasuda N (2007) Perforation of Meckel's diverticulum manifesting as aseptic peritonitis in a neonate: Report of a case. Surg Today 37: $881 Y 883$.

21. Aguayo P, Fraser JD, St Peter SD (2009) Perforated Meckel's diverticulum in a micropremature infant and a review of literature. Pediatr Surg Int 25: 539Y541.

22. Alkan M, Guler G, Yildirim F (2009) Perforation of an inflamed Meckel's diverticulum in a new-born: Report of a case. Turk J Gastroenterol 20: 235Y236.

23. Borgi A, Bouziri A, Boujelbene N, Sghairoun N, Belhadj S, et al. (2014) Perforated Meckel's diverticulum in a very preterm baby revealed at birth. Fetal Pediatr Pathol 33: 119-122.

24. Smolkin T, Hayari L, Zohar Y, Steinberg R, Makhoul I (2013) Meckel diverticulum in a premature infant: Too tiny but still perforates. J Pediatr 162: 1075. 